\title{
Ecotoxicity of the isoxaflutole herbicide to soil invertebrates
}

\author{
Ecotoxicidade do herbicida isoxaflutole para invertebrados do solo
}

\author{
Fernanda Benedet de Santo*, Guilherme Alves Ramos, Altair Maçaneiro Ricardo Filho, Cesar \\ Augusto Marchioro, Júlia Carina Niemeyer
}

Universidade Federal de Santa Catarina, Curitibanos, SC, Brasil. *Author for correspondence: fernandadesanto@gmail.com

Submission: 27/03/2019 / Acceptance: 06/03/2020

\begin{abstract}
Isoxaflutole (IFT) is a pre-emergence herbicide used to control of a wide range of broadleaf and grass weeds, especially those resistant to other herbicide classes, such as glyphosate and atrazine. Although its herbicidal potential was identified in the early 90's, IFT is still a new active ingredient in Brazil and little is known about its effects, mainly regarding to ecotoxicity of formulated products to soil macro and mesofauna groups. This study aimed to assess behavioral, acute, and chronical effects (avoidance, lethality, and reproduction) of the commercial product Provence ${ }^{T M} 750$ WG (750 g a.i. $\mathrm{L}^{-1}$ isoxaflutole) on the test organisms Eisenia andrei (earthworms) and Folsomia candida (collembolans) using standardized ISO guidelines. The results showed the avoidance of the earthworm species only at $>300$ times the predicted field doses, as well as a decrease in reproduction over $>150$ times the predicted field dose. Neither the avoidance, nor lethality or reproduction response were found for the collembolan species. The laboratory results showed that it is possible to assume that Provence ${ }^{\mathrm{TM}}$ is not toxic to earthworms and collembolans, even at the highest field dose applied, ensuring the safety of soil communities.
\end{abstract}

KEYWORDS: avoidance behavior tests, earthworms, pesticides, soil ecotoxicology.

\section{RESUMO}

Isoxaflutole (IFT) é um herbicida utilizado para o controle em pré-emergência de uma ampla variedade de plantas daninhas de folha larga e gramíneas, especialmente quando há resistência a outros herbicidas, como glyphosate e atrazine. Apesar de seu potencial como herbicida ter sido identificado no início dos anos 90, IFT ainda é considerado um ingrediente ativo novo no Brasil e pouco se sabe sobre seus efeitos, principalmente acerca da ecotoxicidade dos produtos formulados para grupos da macro e mesofauna do solo. Este estudo teve como objetivo avaliar efeitos comportamentais, agudos e crônicos (fuga, letalidade e reprodução) do produto comercial Provence ${ }^{\circledR} 750$ WG (750 g i.a. $\mathrm{L}^{-1}$ isoxaflutole) nos organismos de teste Eisenia andrei (minhoca) e Folsomia candida (colêmbolo) usando normas padronizadas ISO. Os resultados mostraram que as minhocas apresentam comportamento de fuga apenas em doses $>300$ vezes a dose de campo e redução na reprodução em doses $>150$ vezes a dose de campo. Para os colêmbolos não foi obtida resposta de fuga, letalidade ou reprodução nas doses avaliadas. A partir dos resultados de laboratório, presume-se que o produto comercial Provence ${ }^{\circledR}$ não apresenta toxicidade para minhocas e colêmbolos, mesmo em doses muito acima à dose de campo, garantindo a segurança das comunidades do solo.

PALAVRAS-CHAVE: agrotóxicos, ecotoxicologia terrestre, minhocas, teste de fuga.

\section{INTRODUCTION}

Isoxaflutole (IFT) is the common name for (5-cyclopropyl-1,2-oxazol-4-trifluoro-2-mesyl-p-tolyl) methanone and belongs to the isoxazoles chemical group. It is used in maize and sugarcane crops to control pre-emergence narrowleaf and broadleaf weeds (PALLETT et al. 2001). When in the soil, water or plant, the IFT quickly turn into diketonitrile (DKT), a stable molecule responsible for degrading (4-hydroxyphenyl) pyruvate dioxygenase (HPPD), an enzyme that causes the disruption of carotenoid synthesis, developing a characteristic bleaching on foliar tissue (RICE et al. 2004, CAVALIERI et al. 2008).

The use of IFT is effective specially against weeds resistant to other herbicide classes, such as glyphosate and atrazine. In 2013, Bayer Crop Science developed a genetically modified (GM) soybean (Glycine max L.) event tolerant to glyphosate and IFT herbicides. This event has acquired a regulatory 
approval for use in food, feed, and crops in Brazil in 2015 (ISAAA 2018). This event joins seventeen another GM soybean already regulated in Brazil with IFT becoming more expressive in the country sales.

Uncertainties concerning to ecotoxicity of herbicide formulation are specially related to surfactants (inert substances) which, in some cases, can present higher toxicity when compared to the active ingredient (a.i.) itself (GIESY et al. 2000, AGUIAR et al. 2016). Some authors describe the toxicity of inert substances as often more toxic to non-target living organisms than the a.i (TOMINACK et al. 2000, COX \& SURGAN 2006). In this context, rapid sublethal toxicity assessments are of great importance given its ecologically relevant outcome concerning the potential damages on non-target organisms (MARQUES et al. 2009). In contrast, reproduction test is a common laboratory requirement for assessing the effects of chemicals. Despite being time-consuming, it is relevant on population parameters since it indicates long-term toxicity effects on non-target organisms and, consequently, on the ecosystem functions and services it provides (HANDY et al. 2012, SALVIO et al. 2016).

A report published in 2003 (EC 2003) showed endocrine effects caused by IFT, classifying it as "toxic to reproduction" for humans. In 2016, the EFSA peer review (EFSA 2016) could not identify endocrine disrupting potential but showed a high risk to mammals (for all representative uses), maintaining the classification of "toxic to reproduction category 2" and reclassifying it as "carcinogenic category 2". On the other hand, according to this report, the substance showed low toxicity to soil arthropods and macro and microorganisms. Besides the EFSA peer review, there is no information on the toxicity effects of IFT to earthworms and collembolans on the available databases.

As representative of soil macrofauna, earthworms regulate many soil processes and functions, such as soil structure, organic matter decomposition, and microbial and invertebrate population, as well as plant growth (LAVELLE 2011). Their representativeness on soil biomass and sensitivity to soil pollutants make them suitable test organisms for the risk assessment of pesticides (SALVIO et al. 2016). Considered another soil ecosystem key-group (DOMENE et al. 2010), collembolans can accelerate organic matter decomposition rates by $20 \%$ and interact with the biological, biochemical, and physical processes (LINS et al. 2007, KORBOULEWSKY et al. 2016).

Although its potential as herbicide was identified in 1991, IFT is still a new active ingredient in the Brazilian market and little is known about its effects on soil fauna, especially regarding ecotoxicity. The aim of this work was to evaluate the ecotoxicity of a formulated product of IFT to soil macro and mesofauna groups represented by the earthworm species Eisenia andrei Bouché, 1972 (Annelida: Lumbricidae) and the collembola species Folsomia candida Willem, 1902 (Collembola: Isotomidae) using standardized ISO guidelines for acute and chronical effect assessment.

\section{MATERIAL AND METHODS}

Provence $^{T M} 750$ WG (750 g a.i. $\mathrm{L}^{-1}$ isoxaflutole), marketed in Brazil by BASF S.A., is a water dispersible granule herbicide recommended for application in pre-emergence weeds in crops of cassava,

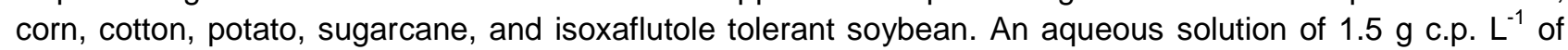
Provence $^{\mathrm{TM}} 750 \mathrm{WG}$ was prepared for the experiment of spiking the soil. The spiking procedure followed the method described by de Santo et al. (2018) and consisted of a range of concentrations of the product plus a negative control (soil with distilled water) (Table 1). To estimate predicted field dose (PFD) the equation described by JANSCH et al. (2006) was used:

$$
M C 5=\frac{\frac{F \cdot D}{A z}}{p}
$$

Where:

MC5 = maximum concentration of pesticide in the top $5 \mathrm{~cm}$ of soil $\left(\mathrm{mg} \mathrm{kg}^{-1}\right)$

$\mathrm{F}=$ conversion factor from $\mathrm{kg} \mathrm{ha}^{-1}$ to $\mathrm{mg} \mathrm{m}^{2^{-1}}$

$\mathrm{D}=$ nominal treatment (application concentration in $\mathrm{kg} \mathrm{ha}^{-1}$ )

$\Delta \mathrm{z}=$ layer of thickness $(0.05 \mathrm{~m})$

$\mathrm{p}=$ dry bulk density $\left(\mathrm{kg} \mathrm{m}^{3^{-1}}\right)$

The top $5 \mathrm{~cm}$ of the soil are considered relevant because of the exposure of soil invertebrates. A standardized soil bulk density of $1,5 \mathrm{~kg} \mathrm{~m}^{3-1}$ was adopted (EPPO 2003). According to the label, the highest 
recommended dose of Provence ${ }^{\mathrm{TM}} 750 \mathrm{WG}$ is $467 \mathrm{~g}$ a.i. ha ${ }^{-1}$, a pre-emergence concentration for sugarcane on clay soil, which was considered in this calculation.

Table 1. Summary of the tests performed with Provence ${ }^{\mathrm{TM}} 750 \mathrm{WG}\left(750 \mathrm{~g} \mathrm{~L}^{-1}\right.$ isoxaflutole).

\begin{tabular}{lll}
\hline Organism & Endpoint & Concentration range $\left(\mathrm{mg} \mathrm{a.i.} \mathrm{kg}^{-1}\right)$ \\
\hline \multirow{2}{*}{ E. andrei } & Avoidance & $0 ; 11.7 ; 23.4 ; 46.9 ; 93.8 ; 187.5 ; 375$ \\
\cline { 2 - 3 } & Lethality & $0 ; 23.4 ; 46.9 ; 93.8 ; 187.5 ; 375$ \\
\cline { 2 - 3 } & Reproduction & $0 ; 23.4 ; 46.9 ; 93.8 ; 187.5 ; 375$ \\
\hline \multirow{2}{*}{ F. candida } & Avoidance & $0 ; 11.7 ; 23.4 ; 46.9 ; 93.8 ; 187.5 ; 375$ \\
\cline { 2 - 3 } & Lethality & $0 ; 23.4 ; 46.9 ; 93.8 ; 187.5 ; 375$ \\
\cline { 2 - 3 } & Reproduction & $0 ; 23.4 ; 46.9 ; 93.8 ; 187.5 ; 375$ \\
\hline
\end{tabular}

Tropical artificial soil (TAS) was used in all tests. Adapted from GARCíA (2004), the used TAS was composed of $75 \%$ fine sand (washed and dried), $20 \%$ kaolin clay, and $5 \%$ coir dust (dried at $60{ }^{\circ} \mathrm{C}$ ), reducing organic matter (from $10 \%$ to $5 \%$ ) to make it more representative of natural soils (OECD 2016). The pH of the TAS was $6.0 \pm 0.5$, adjusted with $\mathrm{CaCO}_{3}$ when necessary. TAS moisture was $50 \%$ of the water holding capacity, adjusted at the beginning of the tests with the addition of distilled water.

The ecotoxicity tests were carried out with the earthworm species $E$. andrei and collembola species $F$. candida preserved in climatic chambers regulated at $20{ }^{\circ} \mathrm{C} \pm 2{ }^{\circ} \mathrm{C}$ and photoperiod of $12: 12 \mathrm{~h}$ light: dark.

According to ISO 11268-1 (ISO 2012a), earthworms were cultured in a moistened mixture of cow manure, free of antibiotics, and coconut powder, being fed once a week with cooked oat. The earthworms were kept in plastic boxes (approximately $10 \mathrm{~L}$ volume) and clitellate organisms (2-12 months old) were used for the avoidance, lethality, and reproduction tests.

According to the ISO 11267 (ISO 2011a), the collembolans were maintained in cultured vessels with a mixture of Paris plaster and activated charcoal $(10: 1)$, being fed twice a week with biological dry yeast (Saccharomyces cerevisiae). Juveniles (10-12d old) were used in the reproduction test while three-month-old adults were used in the avoidance and lethality tests.

To perform the avoidance tests, five replicates were used for both earthworms and collembolans, according to the ISO 17512-1 (ISO 2008) and ISO 17512-2 (ISO 2011b) guidelines. A division was made with a removable plastic divider allowing the test vessel to receive $300 \mathrm{~g}$ of control soil in one side and $300 \mathrm{~g}$ of contaminated soil in the other. After removing the divider, 10 earthworms were placed in the centre of the vessel. The time of incubation was $48 \mathrm{~h}$. The number of earthworms in each compartment was recorded after reinserting the divider.

The same procedure was done for collembolans, but the amount of soil in each side was $30 \mathrm{~g}$ instead of $300 \mathrm{~g}$ and the number of organisms used was 20 instead of 10 . Water and stamp ink were added at the end of the test to allow the visualization of juveniles.

A dual control test was performed for both earthworms and collembolans, allowing to infer a random distribution of organisms. The methodology was the same, but instead of contaminated soil, both sides received control soil.

The lethality tests with earthworms and collembolans lasted 14 days, according to the ISO 11268-1 (ISO 2012a) and 11267 (ISO 2011a) guidelines.

Tests were performed with a control moistened with distilled water. For earthworms, ten clitellate organisms were placed in each test vessels (350 g of contaminated or control TAS), without food, covered with perforated plastic lids allowing aeration. The moisture adjustment was done seven days after the beginning of the tests with the addition of a few drops of distilled water after weighting the replicates. Survival was recorded 14 days after beginning the tests. For collembolans, ten organisms from synchronized cultures (approximately three months old) were placed into test vessels (30 $\mathrm{g}$ of contaminated or control TAS) without food. After 14 days, water and stamp ink were added allowing the counting the floating organisms. Survivals were recorded.

The reproduction tests were performed following the ISO 11268-2 (ISO 2012b) and 11267 (ISO 
2011a) guidelines.

The test with earthworms were carried out using ten clitellate organisms for each replicate containing $350 \mathrm{~g}$ of contaminated or control soil. Cow dung free of antibiotics ( $5 \mathrm{~g}$, dry and ground) was added weekly to feed the organisms. Drops of distilled water were used to replace lost moisture. Four weeks after the beginning of the test ( 28 days), the adults were removed, and the cocoons left to hatch for an additional 28 days. Four weeks later (56 days), the tests vessels were immersed in bain-marie $(55-60 \stackrel{\circ}{\circ})$ allowing the count of juveniles at the soil surface.

The test with collembolans was carried out using ten organisms of 10-12 days of age placed into test vessels with $30 \mathrm{~g}$ of contaminated or control soil. At the beginning of the test and 14 days after, $2 \mathrm{mg}$ of dry yeast was added to feed the organisms. Weekly, drops of distilled water were added to replace lost moisture, and twice a week, test vessels were opened to allow gas exchange. Four weeks after the test began (28 days), water and stamp ink were added and carefully stirred. Photographs were taken and the floating juveniles were counted using the ImageJ software (SCHNEIDER et al. 2012).

The Fisher exact test $(p<0.05)$ was performed to analyze the results obtained in the avoidance tests. According to NATAL-DA-LUZ et al. (2004), the premise of this test is an equal distribution among both tested sides.

Analysis of Variance (ANOVA) was used to test the mean number of juveniles, followed by the Dunnett test $(p<0.05)$, which compared the reproduction in contaminated versus control soil. Normal distribution of data and variance homogeneity were verified using the Shapiro Wilk's test and Bartlett test, respectively.

\section{RESULTS AND DISCUSSION}

After 48 hours of exposure, all the premises were assumed following the ISO validation criteria.

Earthworms avoided IFT only at the concentrations of 187.5 and $375 \mathrm{mg} \mathrm{a}^{\mathrm{i}} \mathrm{k} \mathrm{kg}^{-1}$, equivalent to $>300$ and $>600$ times the recommended doses of the commercial product. Collembolans showed non-avoidance behavior when exposed to IFT, even at the highest concentration tested $\left(375 \mathrm{mg} \mathrm{kg}^{-1}\right)$ equivalent to $>600$ times the maximum recommended dose (Figure 1). In general, the non-avoidance of earthworms and collembolans can be expected when this product is applied to the soil, corroborating with the data found by EFSA (2016).
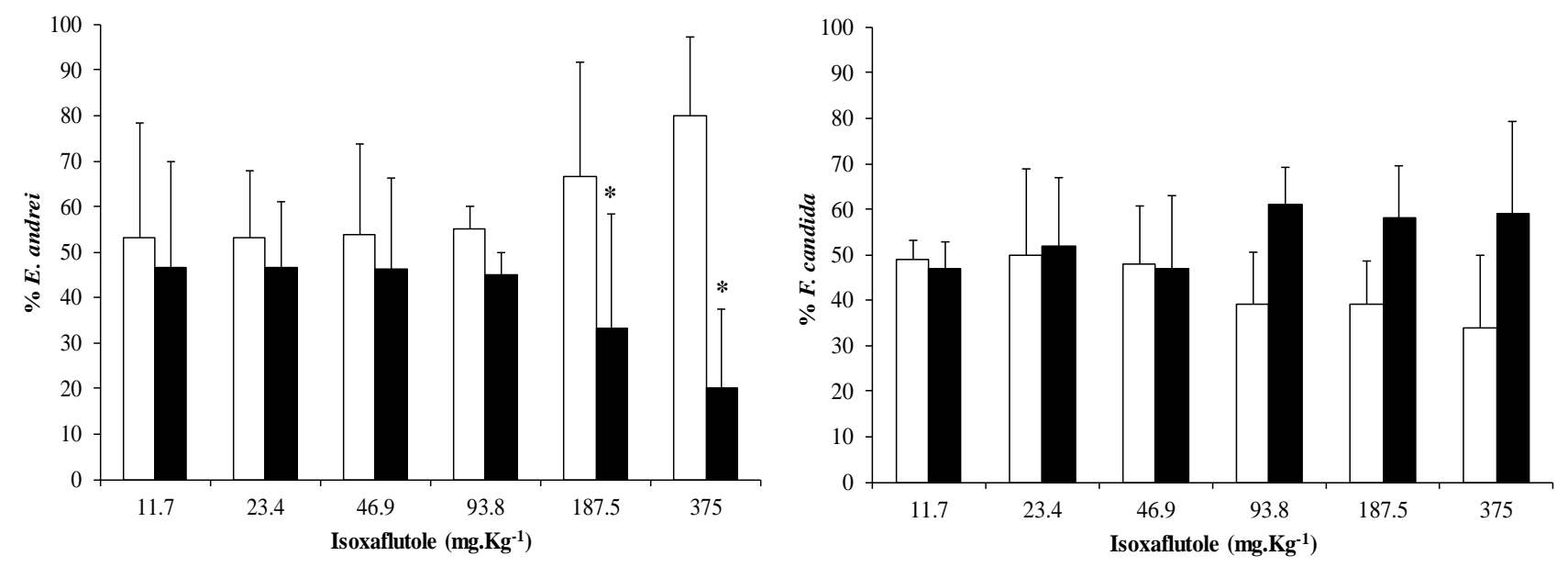

Figure 1. Avoidance tests with $E$. andrei and F. candida: Percentage of organisms on isoxaflutolecontaminated soil (black bars) against the control (white bars). *Asterisks indicate statistical differences $(p<0.05)$.

There was no lethality to collembolans and earthworms (Figure 2) even at concentrations $>600$ times the maximum recommended dose $\left(375 \mathrm{mg}\right.$ a.i. $\left.\mathrm{kg}^{-1}\right)$. In general, the tested product cause non-acute effects on these groups of organisms.

The reproduction tests showed no impairment on the number of collembolan juveniles (Table 2). The toxicity effects on earthworm reproduction can be expected over 150 times the FPD, but these values are not used under field conditions (Table 2). 

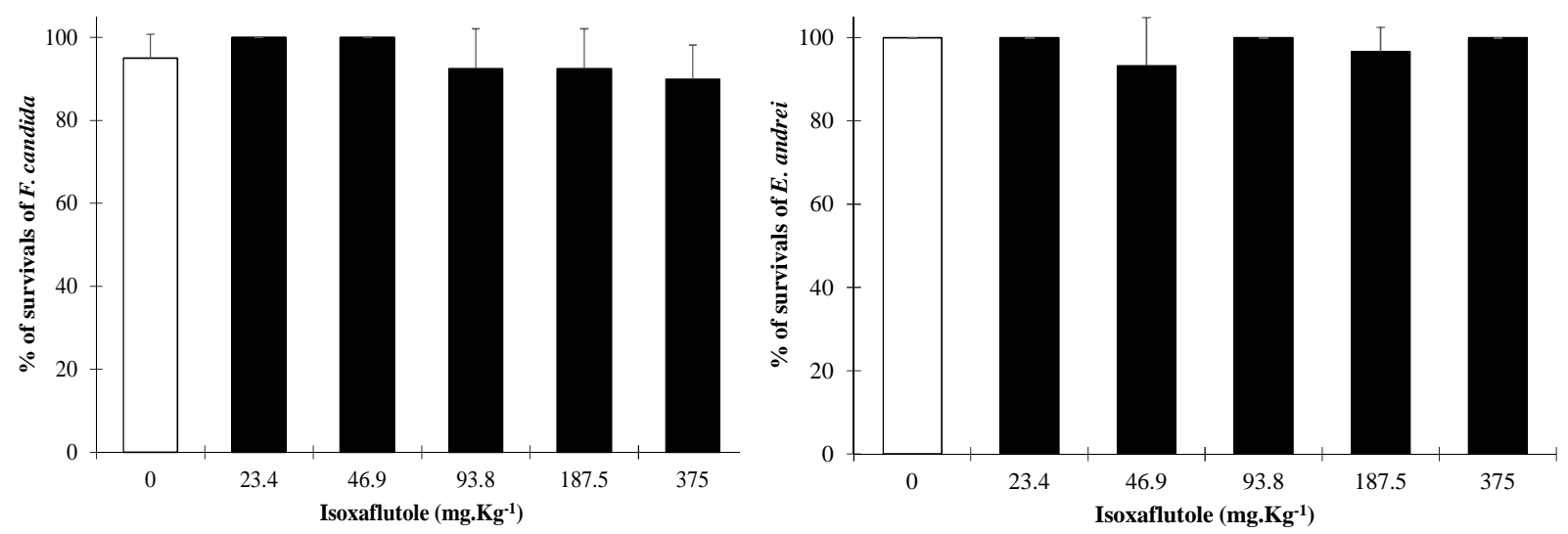

Figure 2. Lethality tests with E. andrei and F. candida: Survival number of organisms on isoxaflutolecontaminated soil (black bars) and the control (white bars). No statistical difference was recorded.

Table 2. Reproduction of the collembolans $F$. candida and the earthworm $E$. andrei exposed to isoxaflutole and its predicted field dose (PFD) according to the nominal dose (isoxaflutole $\mathrm{mg} \mathrm{kg}^{-1}$ ).

\begin{tabular}{|c|c|c|c|c|}
\hline \multirow{2}{*}{ Treatment } & \multirow{2}{*}{$\begin{array}{l}\text { Isoxaflutole } \\
\left(\mathrm{mg} \mathrm{kg}^{-1}\right)\end{array}$} & \multirow{2}{*}{ FPD } & \multirow{2}{*}{$\frac{F . \text { candida }}{\text { Number of juveniles }}$} & \multirow{2}{*}{$\frac{E . \text { andrei }}{\text { Number of juveniles }}$} \\
\hline & & & & \\
\hline Control & 0 & & $510.8 \pm(69.05)$ & $42.00 \pm(9.38)$ \\
\hline Provence ${ }^{\circledR}$ & 23.4 & $>35$ & $541.00 \pm(86.35)$ & $47.25 \pm(19.87)$ \\
\hline \multirow[t]{4}{*}{750 WG } & 46.9 & $>70$ & $580.40 \pm(112.16)$ & $19.50 \pm(4.12)$ \\
\hline & 93.8 & $>150$ & $597.25 \pm(68.15)$ & $16.75 \pm(11.02)^{*}$ \\
\hline & 187.5 & $>300$ & $631.50 \pm(81.42)$ & $24.50 \pm(7.23)$ \\
\hline & 375 & $>600$ & $627.50 \pm(85.41)$ & $30.00 \pm(11.46)$ \\
\hline
\end{tabular}

${ }^{\star}$ Asterisks indicate significant differences in Dunnet test $(p<0.05)$.

Although showing carryover effects to some crops, such as beans and sugar beets (NELSON \& PENNER 2005), there were no toxicity effects to the soil fauna in a real scenario. Few studies testing other herbicides, such as atrazine, pendimethalin, and glyphosate with $E$. andrei (CHELINHO et al. 2010, BUCH et al. 2013) and $F$. candida (BELDEN et al. 2005, AMORIM et al. 2012) found the $\mathrm{CE}_{50}$ or $\mathrm{CL}_{50}$ values for test organisms, showing the low toxicity of herbicides in general.

\section{CONCLUSION}

The results showed avoidance of the earthworm species only at $>300$ times the PFD as well as reproduction response over $>150$ times the PFD. Non-avoidance, lethality or reproduction response was found regarding the collembolan species. From the laboratory results, it is possible to conclude that Provence $^{\mathrm{TM}} 750 \mathrm{WG}$ has no toxicity effects on earthworms and collembolans even at the highest applied field dose, ensuring the safety of macro and mesofauna soil communities.

The ecotoxicity of herbicides depends on their chemical group, commercial formulation, application rates, environmental conditions, and ecological receptors involved. Therefore, it is impossible to extrapolate its toxicity to aquatic ecosystems or humans.

\section{ACKNOWLEDGEMENTS}

This study was funded by the Coordenação de Aperfeiçoamento de Pessoal de Nível Superior (CAPES) by granting a master's degree fellowship (88887.178188/2018-00) to F.B. de Santo. 


\section{REFERENCES}

AGUIAR LM et al. 2016. Glyphosate based herbicide exposure causes antioxidant defence responses in the fruit fly Drosophila melanogaster. Comparative Biochemistry and Physiology Part C: Toxicology \& Pharmacology 185-186: 94101.

AMORIM MJ et al. 2012. Assessing single and joint effects of chemicals on the survival and reproduction of Folsomia candida (Collembola) in soil. Environmental Pollution 160: 145-152.

BELDEN JB et al. 2005. Toxicity of pendimethalin to nontarget soil organisms. Bulletin of Environmental Contamination and Toxicology 74: 769-776.

BUCH AC et al. 2013. Toxicity of three pesticides commonly used in Brazil to Pontoscolex corethrurus (Müller, 1857) and Eisenia andrei (Bouché 1972). Applied Soil Ecology 69: 32-38.

CAVALIERI SD et al. 2008. Tolerance of corn hybrids to nicosulfuron. Planta Daninha 26: 203-214.

CHELINHO S et al. 2010. Cleanup of atrazine-contaminated soils: ecotoxicological study on the efficacy of a bioremediation tool with Pseudomonas sp. ADP. Journal of Soils and Sediments 10: 568-578.

COX C \& SURGAN M. 2006. Unidentified inert ingredients in pesticides: implications for human and environmental health. Environmental Health Perspectives 114: 1803-1806.

DOMENE X et al. 2010. Role of soil properties in sewage sludge toxicity to soil collembolans. Soil Biology and Biochemistry 42: 1982-1990.

EC. 2003. European Commission. Technical Guidance Document on Risk Assessment Part II. Ispra: Joint research Centre. 337p.

EFSA. 2016. European Food Safety Authority. Conclusion on the peer review of the pesticide risk assessment of the active substance isoxaflutole. EFSA Journal 14: 4416.

EPPO. 2003. European Plant Protection Organization. Environmental Risk Assessment scheme for plant protection products. EPPO Bulletin 33: 151-162.

GARCÍA MVB. 2004. Effects of pesticides on soil fauna: Development of ecotoxicological test methods for tropical regions. Ecology and Development Series 19: 291.

GIESY JP et al. 2000. Ecotoxicological risk assessment for Roundup ${ }^{\circledR}$ herbicide. Reviews of Environmental Contamination and Toxicology 167: 35-120.

HANDY RD et al. 2012. Practical considerations for conducting ecotoxicity test methods with manufactured nanomaterials: what have we learnt so far? Ecotoxicology 21: 933-972.

ISAAA. 2018. International Service for the Acquisition of Agri-biotech Applications. Available in: http://www.isaaa.org/ Access in: 22 may 2018.

ISO. 2008. International Organization For Standardization. ISO 17512-1. Soil quality - Avoidance test for determinig the quality of soils and effects on behaviour - Part 1: Test with earthworms (Eisenia fetida and Eisenia andrei). Genebra: ISO.

ISO. 2011a. International Organization For Standardization. ISO 11267. Soil quality - Inhibition of reproduction of Collembola (Folsomia candida) by soil pollutants. Genebra: ISO.

ISO 17512-2. 2011b. International Organization For Standardization. Soil quality - Avoidance test for determining the qualite of soils and effects of chemicals on behavior - Part 2: Test with collembolans (Folsomia candida). Genebra: ISO.

ISO 11268-1. 2012a. International Organization For Standardization. Effects of pollutants on earthworms - Part 1: Determination of acute toxicity to Eisenia fetida/Eisenia andrei. Genebra: ISO.

ISO 11268-2. 2012b. International Organization For Standardization. Soil quality - Effects of pollutants on earthworms Part 2: Determination of effects on reproduction of Eisenia fetida/Eisenia andrei. Genebra: ISO.

JANSCH S et al. 2006. Effects of pesticides on soil invertebrates in model ecosystem and field studies: a review and comparison with laboratory toxicity data. Environmental Toxicology and Chemistry 25: 2490-2501.

KORBOULEWSKY N et al. 2016. How tree diversity affects soil fauna diversity: a review. Soil Biology and Biochemistry 94: 94-106.

LAVELLE P. 2011. Earthworms as Ecosystem Engineers. In: GLIŃSKI J et al. (Eds.). Encyclopedia of Agrophysics. New York: Springer. p. 233-235.

LINS VS et al. 2007. The effect of the glyphosate, 2,4-D, atrazine e nicosulfuron herbicides upon the Edaphic collembola (Arthropoda: Ellipura) in a no tillage system. Neotropical Entomology 36: 261-267.

MARQUES CR et al. 2009. Using earthworm avoidance behaviour to assess the toxicity of formulated herbicides and their active ingredients on natural soils. Journal of Soils Sediments 9: 137-147.

NATAL-DA-LUZ T et al. 2004. Avoidance tests with collembola and earthworms as early screening tools for site-specific assessment of polluted soils. Environmental Toxicology and Chemistry 23: 2188-2193.

NELSON EA \& PENNER D. 2005. Sensitivity of selected crops to isoxaflutole in soil and irrigation water. Weed Technology 19: 659-663.

OECD. 2016. The Organisation for Economic Co-Operation and Development. Test No. 226: Predatory mite (Hypoaspis 
(Geolaelaps) aculeifer) reproduction test in soil. Paris: OECD.

PALLETT KE et al. 2001. Isoxaflutole: the background to its discovery and the basis of its herbicidal properties. Pest Management Science 57: 133-142.

RICE PJ et al. 2004. Effect of soil properties on the degradation of isoxaflutole and the sorption-desorption of isoxaflutole and its diketonitrile degradate. Journal of Agricultural and Food Chemistry 52: 7621-7627.

SALVIO C et al. 2016. Survival, Reproduction, Avoidance Behavior and Oxidative Stress Biomarkers in the Earthworm Octolasion cyaneum Exposed to Glyphosate. Bulletin of Environmental Contamination and Toxicology 96: 314-319.

SCHNEIDER CA et al. 2012. NIH Image to ImageJ: 25 years of image analysis. Nature Medicine 9: 671-675.

TOMINACK RL. 2000. Herbicide formulations. Journal of Toxicology 38: 129-135. 